\title{
DINAMIKA HOAX, POST-TRUTH DAN RESPONSE READER CRITICISM DALAM REKONSTRUKSI KEHIDUPAN BERAGAMA
}

\author{
Sonny Eli Zaluchu \\ Sekolah Tinggi Teologia Baptis Indonesia (STBI) Semarang \\ Email: sonnyzaluchu@stbi.ac.id
}

\begin{abstract}
This research is conducted through literature review to expose and analyze hoax phenomenon, post-truth paradigm, and readerresponse criticism. This paper aims to elucidate the social extent to which hoaxes are formed as a result of the presence of post-truth paradigm in the mind of information waves as well as the impact of the digital revolution. The phenomenon will be described through hermeneutical method using reader-response criticism approach in the context of religious life. The research found that spiritual life can be developed in the right way through media-literacy, besides the spread of hoaxes, disinformation, and truth-oriented personal beliefs rather than facts.
\end{abstract}

Penelitian ini dilakukan melalui review literatur untuk memaparkan dan menganalisis fenomena hoax, paradigma post-truth dan reader response criticism. Artikel ini bertujuan untuk melihat sejauh mana hoax terbentuk sebagai akibat hadirnya paradigma post-truth di masyarakat yang tengah dilanda badai informasi, sebagai dampak revolusi digital. Fenomena tersebut dianalisis menggunakan metode hermeneutika, yakni pendekatan reader response criticism, dalam konteks 
kehidupan umat beragama. Hasil temuan memperlihatkan bahwa sekalipun hidup di dalam dunia yang penuh dengan hoax, disinformasi dan kebenaran yang berorientasi pada keyakinan pribadi daripada fakta, kehidupan rohani (spiritualitas) tetap dapat dikembangkan dengan cara yang benar melalui literasi media dan edukasi bahwa internet dan semua produk yang menyertainya juga memiliki sisi buruk sehingga harus disikapi dengan bijak.]

Keywords: hoax, post-truth, reader response criticism, spirituality, and media literation.

\section{Pendahuluan}

Dunia sedang berubah. Informasi menyebar dengan cepat dan menembus dinding-dinding pembatas yang yang selama ini sulit ditembus secara konvensional. Dalam kacamata informasi, dunia terlihat menjadi sangat global, transparan dan tanpa sekat. Semua orang dapat melihat apa saja, melakukan apa saja, mulai dari membeli hingga menjajakan sesuatu. Savitri mengatakan, perubahan itu menuntut setiap orang melakukan penyesuaian jika tidak ingin tertinggal. ${ }^{1}$

Peradaban mengalami perubahan yang drastis dan kontras. Akan tetapi, tanpa disadari, perubahan tersebut membawa dampak, baik positif maupun negatif di dalam gaya hidup sosial. Internet menjadi kanal informasi yang hampir tidak dapat dikontrol. Pengetahuan apapun terdapat di sana. Dalam dunia pendidikan, misalnya, internet sangat berperan positif dalam menjadi alat edukasi murid-murid, terlebih sebagai media pembelajaran yang dapat diakses dengan mudah dan cepat. ${ }^{2}$ Tetapi hal positif tersebut tidak serta-merta menghilangkan dampak negatif. Penelitian yang dilakukan Fitri kepada anak-anak Sekolah Dasar untuk melihat

1 Astrid Savitri, Revolusi Industri 4.0: Mengubah Tantangan Menjadi Peluang di Era Disrupsi 4.0 (Yogyakarta: Penerbit Genesis, 2019).

2 Sriyono Sriyono, "Internet Sebagai Media Pembelajaran," Prosiding Seminar Nasional Pendidikan KALUNI, 2018. (https://doi.org/10.30998/prossnp.v1i0.29). 
ketergantungan terhadap internet dan gadget memperlihatkan adanya perubahan di dalam perilaku sosial saat berada di dalam komunitas. Penelitian ini memperoleh hasil adanya kecanduan pada internet dan sikap antisosial akibat ketergantungan yang tinggi terhadap media sosial ${ }^{3}$ dan munculnya perilaku cyberbullying di kalangan remaja. ${ }^{4}$ Fenomena demi fenomena tersebut menjelaskan satu hal, bahwa baik buruknya internet dan revolusi informasi lebih disebabkan oleh tujuan dan manfaat yang ingin dicapai oleh setiap orang yang memanfaatkannya.

Tiga tahun setelah kata post-truth dijadikan Word of the Year oleh Oxford tahun 2016, istilah ini menyebar pemanfaatannya bagai epidemi sosial di dunia informasi. Tidak banyak pembahasan positif yang mencuat tentang kata ini di tengah kehidupan sosial politik dunia. Kata ini lebih dikaitkan sebagai dampak buruk dari era revolusi digital yang melanda dunia, melebihi dampak ketika terjadi revolusi industri beberapa abad silam. Penelitian yang dilakukan oleh Kharisma Dhima Syuhada dan dilaporkan dalam Jurnal Komunikasi Indonesia menyimpulkan bahwa salah satu masalah sosial yang terjadinya akibat revolusi digital adalah informasi yang datang membanjiri semua sisi kehidupan masyarakat ibarat air bah yang tak dapat dibendung. ${ }^{5}$ Masalah terjadi manakala masyarakat gagal mencerna setiap informasi tersebut dan menerima mentahmentah semua yang disajikan oleh internet, tanpa menguji kebenarannya.

Sebagaimana pengalaman Indonesia di masa pemilihan umum presiden 2019, hegemoni media mainstream terhadap berita telah membangkitkan sentimen yang berlawanan di kalangan media sosial dan media online sebagai pilihan alternatif sumber informasi masyarakat. Situasi ini menjadi bola salju yang menggelinding karena media online dan media sosial justru dimanfaatkan secara tidak

3 Sulidar Fitri, "Dampak Positif dan Negatif Sosial Media," Naturalistic: Jurnal Kajian Penelitian Pendidikan Dan Pembelajaran, Vol 1, No. 2 (April, 2017). (https://doi.org/10.35568/naturalistic.v1i2.5).

${ }^{4}$ Sartana dan Nelia Afriyeni, "Perilaku Perundungan Maya (Cyberbullying) Pada Remaja Awal," Jurnal Psikologi Insight @ Psikologi Universitas Pendidikan Indonesia, Vol. 1, no. 1, (April 2017). (https://doi.org/10.5281/zenodo.576972).

5 Kharisma Dhimas Syuhada, "Etika Media Di Era 'Post-truth," Jurnal Komunikasi Indonesia, 2018. ( https://doi.org/10.7454/jki.v6i1.8789). 
bertanggung-jawab oleh berbagai pihak yang berkepentingan dan mengubahnya menjadi kanal berita palsu yang menyesatkan informasi dan menyebarkan hoax. Di sisi lain, masyarakat akhirnya digiring untuk terbiasa dengan pemelintiran informasi tersebut dan tanpa sadar justru menjadi bagian dari pembentukan dan penyebaran hoax itu sendiri. Penelitian yang dilakukan menggunakan Social Network. Analysis oleh Karimi dkk, mendukung hal tersebut. Penelitian ini dijalankan dalam rentang satu bulan pengamatan, ditemukan 18 di dalam satu bulan tersebut dimana kata kunci hoax menjadi trending topic di Twitter. Penulis menyimpulkan bahwa terdapat 58\% pengguna Twitter yang sering berbicara tentang kebohongan (Karimi, Arini, Masruroh, \& Mintarsih, 2019). Situs berita online detik.com melaporkan hal senada, bahwa pemerintah melalui Kominfo berhasil menemukan sebaran informasi hoax yang terjun bebas di tengah masyarakat, tanpa terkendali. ${ }^{6}$

Hoax sebagai informasi yang dipelintir untuk kepentingan tertentu menjadi sebuah gelombang yang membawa titik-titik gelombang baru. Satu gelombang informasi yang menyesatkan ketika tiba pada targetnya berubah menjadi sumber-sumber gelombang baru dan menyebar dengan cepat. Maka yang terjadi adalah disinformasi, miskomunikasi dan pembelokan kebenaran. Semua hal itu mengarah pada satu hal yakni kekacauan (chaos). Kenyataan tersebut membangkitkan rasa ingin tahu untuk meneliti sejauh mana hoax terbentuk sebagai akibat hadirnya paradigma posttruth di dalam benak masyarakat yang tengah berada di dalam derasnya laju revolusi digital. Terlebih jika dikaitkan dengan hermeneutika makna menggunakan pendekatan reader response criticism. Untuk memenuhi tujuan itulah paper ini disusun.

Penelitian dilakukan dengan studi literatur ${ }^{7}$ khususnya untuk memaparkan konsep-konsep utama dan definitif tentang poin-poin penting penelitian. Pertama-tama dipaparkan tentang hoax, kemudian penjelasan tentang paradigma post-truth dan ditutup dengan bagaimana kedua konsep ini dapat saling terkait. Langkah berikutnya adalah menjelaskan konsep kritik respon pembaca

\footnotetext{
6 Andhika Akbarayansyah, "771 Hoax Berhasil Diidentifikasi Kominfo," (detik.com, 2019).

7 Joy Don Baker, "The Purpose, Process, and Methods of Writing a Literature Review," AORN Journal 103, no. 3 (2016): 265-69. (https://doi.org/10.1016/j.aorn.2016.01.016).
} 
(reader response criticism) sebagaimana dikemukakan oleh Osborne $^{8}$ dan melihat hubungan langsung kritik jenis ini terhadap munculnya hoax akibat dukungan paradigma post-truth. Hasil yang diharapkan adalah penjelasan deskriptif, sistematis dan analitik tentang bagaimana paradigma post-truth tersebut menjadi katalis di dalam pembentukan hoax melalui kritik respon pembaca.

\section{Fenomena Hoax}

Definisi KBBI tentang kata ini sangat ringkas. Hoax adalah sebuah berita bohong. ${ }^{9}$ Sebagai sebuah informasi yang disampaikan ke public space, hoax mengandung konten yang berisi hal-hal yang belum pasti atau tidak sesuai dengan fakta yang terjadi. Masyarakat Telematika Indonesia atau dikenal dengan nama MASTEL, melakukan survei sejak tahun 2017 dalam mendapatkan gambaran masyarakat tentang hoax dan klasifikasinya, pola penyebarannya, serta dampak yang ditimbulkannya secara nasional dalam kehidupan berbangsa.

Survei melibatkan 941 responden selama paruh awal bulan Maret 2019. Mayoritas responden berpendapat bahwa hoax diyakini sebagai berita yang benar dan akurat karena sumbernya layak dipercaya. Sebanyak 63,3\% responden meyakini hoax karena mendapatkan informasi dari orang yang dapat dipercaya. 24,6\% responden menyatakan percaya karena kalimatnya meyakinkan. Sisanya, 8,5\% responden berpendapat terpengaruh sikap dan pilihan politik, 3,6\% responden sebagai akibat terbawa pengaruh ujaran kebencian. Dilihat dari bentuk hoax yang diterima survei tahun 2019 memperlihatkan hasil sebagai berikut: berbentuk tulisan 70,7\% (bandingkan tahun 2017 sebesar 57,9\%), foto dengan caption palsu 66,3\% (bandingkan tahun 2017 sebesar 37.5\%) dan melalui berita/foto/video lama yang di retouching/reposting 69,2\% (bandingkan tahun 2017 sebesar 0.40\%). Angka-angka tersebut memberi informasi tentang adanya peningkatan yang sangat signifikan dalam hal penyebaran hoax. Lebih menarik lagi, sosial media menduduki peringkat tertinggi sebagai media penyalur hoax

8 Grant R. Osborne, The Hermenentical Spiral, 2nd ed. (Downer s Grove, Illionis: IVP Academic, 2006), 567-71.

9 KBBI Online, "Hoax," Badan Pengembangan dan Pembinaan Bahasa, 2016. (https://kbbi.kemdikbud.go.id/entri/hoaks). 
92.40\% (tahun 2017 sebesar 87.50\%), melebihi aplikasi chating dan website. ${ }^{10}$

Kesimpulan yang dapat diperoleh dari survei tersebut adalah tingginya ketergantungan dan keterlibatan masyarakat Indonesia di dalam penyebaran, pemanfaatan dan penggunaan hoax melalui media sosial. Ketidaktahuan di dalam pemanfaatan media sosial secara bijaksana menjadi salah satu penyebab yang mendorong semakin berkembangnya budaya hoax tersebut di tengah masyarakat. Terlebih jika dikaitkan dengan faktor otonomi user yang bebas mengakses internet untuk kepentingan dan keperluan apapun, mendorong orang dengan mudah mengunggah berbagai konten (tulisan, gambar dan video) yang kemudian menyebar cepat di dunia maya. Meskipun para user tersebut pada akhirnya tidak menyadari bahwa konten-konten yang diupload telah melanggar hukum dan etika berkomunikasi dalam media sosial. ${ }^{11}$

Selain disebabkan oleh penggunaan yang tidak bijak akibat ketidaktahuan, hal lain yang mendorong percepatan hoax adalah rendahnya kesadaran terhadap konsekuensi akibat menjadi pelaku penyebaran berita palsu di internet. Padahal, pasal 28 UU Nomor 11 Tahun 2008 tentang Informasi dan Transaksi Elektronik dengan tegas menyatakan: (1) Setiap Orang dengan sengaja, dan tanpa hak menyebarkan berita bohong dan menyesatkan yang mengakibatkan kerugian konsumen dalam Transaksi Elektronik. (2) Setiap orang dengan sengaja dan tanpa hak menyebarkan informasi yang ditujukan untuk menimbulkan rasa kebencian atau permusuhan individu dan/atau kelompok masyarakat tertentu berdasarkan atas suku, agama, ras, dan antar golongan (SARA) akan mendapat ancaman hukumannya yang diatur di dalam pasal 45 ayat 3 UU yang sama. Bahwa setiap orang yang memenuhi unsur sebagaimana dimaksud dalam Pasal 28 ayat (1) atau ayat (2) dipidana dengan

10 Mastel, "Hasil Survey Wabah Hoax Nasional 2019," 2019. (https://mastel.id/hasil-survey-wabah-hoax-nasional-2019/).

${ }^{11}$ Dedi Rianto Rahadi, "Perilaku Pengguna dan Informasi Hoax Di Media Sosial," Jurnal Manajemen dan Kewirausahaan, 2017. (https://doi.org/10.26905/jmdk.v5i1.1342); Srijan Kumar, Robert West, dan Jure Leskovec, "Disinformation on the Web: Impact, Characteristics, and Detection of Wikipedia Hoaxes," dalam The International World Wide Web Conference Com- Mittee (IW3C2), 2016. (https://doi.org/10.1145/2872427.2883085). 
pidana penjara paling lama 6 (enam) tahun dan/atau denda paling banyak Rp1.000.000.000,00 (satu miliar rupiah). Tetapi kenyataannya, sekalipun ancaman hukuman sangat tinggi, akibat rendahnya literasi, masyarakat semakin terlibat di dalam penyebaran hoax melalui media sosial seperti temuan Mantel 2019.

Oleh karena itu, Osler ${ }^{12}$ di dalam Juliswara mengusulkan pentingnya edukasi masyarakat agar dalam mengintegrasikan dirinya menuju peradaban digital, setiap warga negara mengembangkan sikap yang bertanggung-jawab dalam mengelola informasi dan kebebasan hak. ${ }^{13}$ Selain itu, perlu diupayakan naiknya kesadaran individual dan kelompok tentang hak-hak politik, sosial dan budaya, termasuk perihal kebebasan berbicara secara bertanggungjawab dan implikasi sosial yang muncul.

Munculnya hoax tidak dapat dipisahkan dari latar belakang user internet itu sendiri. Pengguna internet yang tidak memiliki kesadaran hukum, minim dalam etika media, akan dengan mudah memanfaatkan media sosial untuk mewujudkan kepentingan pribadi-nya. Contohnya, tebaran hoax yang tajam dan sangat berbahaya di dalam ajang pemilu 2019 yang lalu, telah mengancam sendi-sendi demokrasi di dalam sistem politik Indonesia dan merusak kerukunan umat beragama dengan cara membenturkan penganut melalui isu-isu SARA. ${ }^{14}$ Selain kepentingan politik, hoax juga didorong oleh niat untuk melakukan kejahatan, usaha untuk mendapatkan keuntungan ekonomis, rekayasa publik untuk viral dan mendongkrak popularitas, keterlibatan dalam aneka konspirasi, dan hidup yang penuh kebencian, adalah kepentingan-kepentingan yang dapat diidentifikasi sebagai bagian dari latar belakang pelaku hoax tersebut. Jika demikian, muncul pertanyaan, siapa yang menjadi "kambing-hitamnya"? Apakah pelakunya? Ataukah internet dan media digital atau regulasi?

\footnotetext{
12 Starksey Osler, Changing Citizenship (London: Open University Press, 2005).

13 Vibriza Juliswara, "Mengembangkan Model Literasi Media yang Berkebhinnekaan dalam Menganalisis Informasi Berita Palsu (Hoax) di Media Sosial," Jurnal Pemikiran Sosiologi 4, no. 2 (2017): 142. (https://doi.org/10.22146/jps.v4i2.28586).

14 Renata Anisa and Rachmaniar, "Hoax Politik Pada Media Sosial Instagram (Studi Etnografi Virtual Tentang Keberadaan Instagram dan Hoax Politik)," Prosiding Seminar Nasional Komunikasi 2016, 2016.
} 
Pendapat McLuhan ${ }^{15}$ yang dikutip oleh Gunawan dapat dijadikan acuan untuk memahaminya. ${ }^{16}$ Pakar media ini menjelaskan bahwa hoax bukanlah pesan yang sebenarnya dari peradaban digital. Konten hoax menyebar melalui internet dan teknologi informasi yang bergerak sangat cepat dan tidak terduga, yang berdampak pada perubahan cara hidup seseorang, dan caranya membangun relasi dengan sesama di tengah komunitas. Menurutnya, pesan yang sebenarnya adalah media itu sendiri. Penanganan hoax selama ini salah karena penekanan diarahkan kepada isi hoax daripada pelaku yang menggunakan teknologi media yang membawa atau menjadi saluran pesan itu. Dengan kata lain, hoax hanya bisa dikikis dengan mempersiapkan setiap orang mengalami transisi yang benar dan mengintegrasikan dirinya secara tepat dan fungsional dengan laju dan perubahan teknologi informasi. Masyarakat yang tidak siap dengan perubahan cenderung gagap dan salah tafsir dalam mereposisi dirinya di dalam perubahan. Sebaliknya, masyarakat yang berhasil mengintegrasikan hidupnya dengan perubahan dunia justru akan memetik manfaat dari kemajuan teknologi. Berkaitan dengan informasi, akan memiliki self control yang kuat untuk tidak terlibat di dalam pembuatan, penyebaran dan menjadi korban boax.

\section{Paradigma Post-truth}

Post-truth adalah kata dan istilah yang baru, yang oleh Oxford diterjemahkan sebagai situasi di mana fakta dan realitas tidak lagi menjadi indikator kebenaran melainkan oleh opini orang secara personal berdasarkan emosi dan keyakinannya secara pribadi. Dalam pengertian ini, kebenaran menjadi bias dan sangat subjektif. Fakta dikesampingkan dan yang terutama adalah keyakinan pribadi. ${ }^{17}$ Menurut Hartono, fenomena ini muncul sebagai dampak dari banjirnya informasi dari dunia internet dan miskin literasi para

\footnotetext{
${ }^{15}$ Mashall McLuhan dan Bruce R. Powers, The Global Village: Transformation in World Life and Media (New York: Oxford University Press, 1989).

16 Budi Gunawan dan Barito Mulyo Ratmono, Kebohongan Di Dunia Maya (Jakarta: Kepustakaan Populer Gramedia, 2018), 11.

17 Nick Rochlin, "Fake News: Belief in Post-truth," Library Hi Tech, (2017). (https://doi.org/10.1108/LHT-03-2017-0062).
} 
penggunanya. ${ }^{18}$ Akibatnya, post-truth berkembang menjadi sebuah paradigma di dalam cara seseorang membangun opini di tengah masyarakat. Tidak menjadi persoalan jika opini tersebut bertujuan untuk membangun dan meningkatan daya rekat sosial.

Masalah terjadi jika opini tersebut justru memperlemah ikatan sosial, menghancurkan tatanan dan memecah belah. Itulah sebabnya, post-truth di dalam kerangka pembentukan opini publik yang kemudian disosialisasikan melalui media digital, menjadi alat kepentingan yang sangat efektif memenuhi tujuan penggunanya. Kampanye politik memakai strategi post-truth misalnya, di satu sisi berhasil memenuhi tujuan kampanye untuk mempengaruhi opini masyarakat, tetapi berdampak buruk dalam pendewasaan, karena masyarakat telah terlanjur tumbuh di dalam kebenaran semu yang diusung paradigma ini. ${ }^{19}$ Masyarakat akan lebih percaya pada pendapat atau opini pribadi seseorang daripada kebenaran fakta. Sebagaimana dikatakan Dossey, hal seperti ini akan memicu masyarakat yang sakit baik secara fisik terlebih mental. ${ }^{20}$

Syahputra di dalam bukunya yang berjudul Opini Publik: Konsep, Pembentukan dan Pengukuran ${ }^{21}$ mengatakan bahwa sebuah opini publik memenuhi tiga unsur utama yakni: keyakinan (belief); sikap (attitude); dan persepsi (perception). Keyakinan timbul karena masyarakat akan percaya dan memegang kebenaran yang disampaikan oleh para pembawa opini (pemimpin). Sedangkan sikap bicara tentang apa yang dirasakan oleh seseorang terhadap berita yang disampaikan lewat media khususnya keingintahuan atau sikap pasif. Sementara itu, persepsi bicara tentang bagaimana melalui opini, masyarakat memberikan makna dan merasakan sensasi dari

${ }^{18}$ Dudi Hartono, "Era Post-truth: Melawan Hoax Dengan Fact Checking," Prosiding Seminar Nasional Prodi Ilmu Pemerintaban Fisip Untirta, 2018, 70-82. (http://repository.fisip-untirta.ac.id/952/).

19 Heni Ismiati, Ari Ganjar Herdiansah, dan Junaidi, "Pembelahan Ideologi, Kontestasi Pemilu, dan Persepsi Ancaman Keamanan Nasional: Spektrum Politik Indonesia Pasca 2014?," Jurnal Wacana Politik, Vol. 2, No. 1, (2017).

${ }^{20}$ Larry Dossey, "Post-truth, Truthiness, and Healthcare," Explore: The Journal of Science and Healing, 2017. (https://doi.org/10.1016/j.explore.2017.03.001).

${ }^{21}$ Iswandi Syahputra, Opini Publik: Konsep, Pembentukan dan Pengukuran (Bandung: Simbiosa Rekatama Media, 2018), 35. 
opini tersebut sehingga mendapatkan pengetahuan terbaru. Ketiga unsur tersebut memang menjadi target dari paradigma post-truth tetapi berjalan di dalam agenda setting yang bertolak belakang. Opini seharusnya beranjak dari kebenaran fakta. Tetapi post-truth mengubah kebenaran fakta itu dengan cara memanipulasi dan membelokkannya lalu menciptakan kebenaran baru di atas fakta berdasarkan opini. Akibatnya, perilaku masyarakat berubah dan lebih mengikuti framing informasi yang sudah direkayasa untuk kepentingan pembuatnya. Maka yang terjadi, keyakinan masyarakat bergeser seiring dengan munculnya persepsi yang baru. Akibatnya, terjadi perubahan perilaku.

Sebetulnya, framing adalah hal yang sangat baik untuk menolong seseorang memahami realitas dan mengurangi kebingungan akibat kompleksitas informasi. Teori Goffman dapat dijadikan acuan untuk memahami konsep framing ini melalui buku klasik berjudul Frame Analysis: An Essay on The Organization of Experience. Dikatakannya, sebagaimana dikutip Syahputra, frame menolong untuk mengurangi kompleksitas informasi dan membantu menafsirkan serta melakukan rekonstruksi realitas. ${ }^{22}$ Selanjutnya, frame memiliki akar konseptual dalam fenomenologi, bahwa eksistensi individual di dalam dunia dirasakan oleh setiap individu menurut apa yang diyakini dari kehidupan, pengalaman yang terbentuk dan pengetahuan yang didapatkan. Dengan kata lain, framing yang salah akan membawa dampak langsung pada cara setiap orang memberikan respon terhadap kehidupan yang dijalaninya. Jika respon menjadi salah maka perilaku akan melenceng. Hal inilah yang terlihat di dalam paradigma post-truth, yakni membangun ulang kenyataan dengan desain interpretatif personal dengan memanipulasi frame realitas sehingga informasi yang tidak benar tersebut, pada akhirnya diterima sebagai kebenaran oleh masyarakat dan bertumbuh di dalamnya.

Hal yang sangat memperihatinkan terungkap di dalam penelitian yang dilakukan oleh Utami. Kajiannya difokuskan pada sinergi yang terjadi antara hoax dan paradigma post-truth dalam kampanye politik di Indonesia. ${ }^{23}$ Dia menemukan bahwa isu-isu pokok yang melibatkan SARA seperti komunisme, sentimen anti-

22 Ibid., 101.

23 Pratiwi Utami, "Hoax in Modern Politics," Jurnal Ilmu Sosial dan Ilmu Politik 22, no. 2 (2019): 85. (https://doi.org/10.22146/jsp.34614). 
Cina dan anti-Kristen, ikut berperan di dalam meningkatkan sensitivitas dan sentimen SARA di Indonesia. Penelitiannya yang menyelidiki karakteristik informasi palsu yang beredar di media sosial melihat arus kebohongan berbagai 'meme' dan ide-ide yang menyertainya untuk membentuk opini masyarakat. Akibatnya, muncul kepercayaan bersama yang baru di tengah masyarakat seiring dengan meningkatnya polarisasi. Teknik framing digunakan untuk menggiring keberpihakan politik di tengah masyarakat. Akibat kebenaran yang dikalahkan, orang-orang digiring menjauh dari fakta-fakta dan tumbuh di dalam keyakinan manipulatif. Indikasi yang dikemukakan oleh Llorente terbukti. Objektivitas dan rasionalitas di dalam iklim sosial-politik, membuka jalan yang sangat lebar kepada emosi untuk berpegang kepada keyakinan kendatipun fakta menunjukkan hal yang sebaliknya. ${ }^{24}$

Haryatmoko memberikan solusi yang tidak jauh berbeda dengan ide McLuhan tentang hoax. Akibat post-truth yang lebih mengutamakan emosi daripada rasionalitas dan objektivitas (emosi mengalahkan fakta), diperlukan sebuah kritik diri dengan mulai melakukan literasi yang benar. ${ }^{25}$ Post-truth hanya dapat dihadapi dengan counter information yang digali dari sumber berita terpercaya. Butuh waktu untuk membangun budaya literasi yang demikian tetapi sangat efektif di dalam menangkal disinformasi kebenaran.

Berdasarkan penjelasan ini dapat ditarik sebuah kesimpulan penting bahwa hoax berjalan paralel dengan paradigma post-truth. Bahkan dapat dikatakan merupakan produk dari paradigma tersebut. Hoax berupa konten sementara post-truth adalah paradigmanya. Keduanya memiliki tujuan yang sama yakni membentuk dan membangkitkan prasangka di tengah masyarakat.

\section{Reader Response Criticism}

Reader Response Criticism (RRC) adalah salah satu bentuk kritik modern yang dikembangkan mengikuti konsep hermeneutika postmodern. Kritik ini dikembangkan di dalam asumsi dasar bahwa makna yang ada di dalam sebuah teks selalu memiliki peluang untuk

\footnotetext{
${ }^{24}$ Jose Antonio Llorente, "The Post-truth Era: Reality vs Perception," Uno Magazine, March 2017. (www.U-Magazine.com).

${ }^{25}$ Haryatmoko, "Era Post Truth dan Prasangka Negatif," dalam Agus Suwignyo (ed.), Post-truth Dan (Anti) Pluralisme, (Jakarta: Penerbit Buku Kompas, 2018), 9.
} 
ditemukan. Harus disadari bahwa baik hoax maupun paradigma posttruth selalu mengarah untuk mengembangkan wacana. Di dalam wacana itulah, proses pencarian makna dimulai.

Menurut Badara, media mainstream maupun online melakukan konstruksi realitas dalam bentuk yang lebih bermakna. Media merekonstruksi peristiwa-peristiwa untuk memberitakannya kembali. Prosesnya dimulai dari membangun persepsi terhadap suatu objek yang kemudian dikonseptulisasikan melalui bahasa. Sebab, bahasa mengandung makna. Persoalannya, di dalam media, bahasa bukan hanya semata-mata alat untuk menggambarkan realitas melainkan dapat membentuk dan menentukan citra (gambaran) di dalam benak khalayak. ${ }^{26}$ Kekuatan inilah yang kemudian ditunggangi paradigma post-truth untuk melahirkan hoax. Bahasa diubah sedemikian rupa untuk membentuk citra yang dikehendaki di dalam benak khalayak. Dengan demikian, cara masyarakat mengangkat makna dari teks, sangat menentukan kesimpulan yang diperoleh dan gambaran yang tercipta di dalam benak masyarakat.

Berbeda dengan pandangan hermeneutika tradisional yang fokus pada makna teks dengan melakukan eksegesis, filosofis posttruth menggeser cara orang melakukan hermeneutika. Sumaryono ${ }^{27}$ membela pandangan tersebut melalui sebuah kesimpulan, bahwa hermeneutika tidak dapat dibatasi hanya sebagai metode belaka, melainkan bergantung pada orang yang melakukan interpretasi. Menurutnya, dogma hermeneutika memiliki sifat luwes sesuai perkembangan zaman dengan ciri open-mindedness-nya. Berdasarkan pandangan tersebut, proses penemuan makna dari textbased menjadi reader-based bukan hal yang tabu di dalam pemahaman hermeneutika. Text-based dikembangkan melalui metode eksegesis hingga menemukan arti pada akar kata pembentuknya. Dari sana, konstruksi konseptual tentang makna teks dibangun. Langkah ini menempatkan teks sebagai pusat kajian. Hermeneutika modern berseberangan dengan hal itu. Teks hanya diperlakukan sebagai objek dan yang lebih penting adalah bagaimana pembaca menafsirkan teks tersebut. Post-truth tidak peduli pada teks dan bentuk-bentuknya sebab itu hanya media untuk menyampaikan

26 Aris Badara, Analisis Wacana (Jakarta: Kencana Prenada Media Group, 2014), 8-9.

${ }^{27}$ E. Sumaryono, Hermenetik (Yogyakarta: Kanisius, 2018), 142. 
pesan. Yang menjadi sasaran post-truth adalah citra atau gambaran yang terbentuk di dalam diri pembaca.

Salah satu hermeneutika yang beranjak dari reader-based adalah reader response ciriticsm atau dikenal dengan kritik respon pembaca (selanjutnya RRC). Dalam metode ini, penulis menghasilkan teks sedangkan pembaca mempelajari teks tersebut untuk menarik maknanya. ${ }^{28}$ Pembahasan yang dikemukakan oleh Osborne di dalam bukunya Spiral Hermeneutics menekankan bahwa pembaca pada dasarnya melihat teks dan mencernanya berdasarkan latar belakang dan kecenderungan-kecederungan pribadinya sendiri. Itu sebabnya, masalah penafsiran selalu dimulai dan berakhir dengan kehadiran pembaca. Dalam perspektif ini terjadi pergeseran. Pembaca terlihat sebagai pencipta makna ketimbang teks itu sendiri. Persoalannya, karena pembaca melintasi jalan pikiran penulis melalui berbagai cara untuk menemukan makna, pembaca dapat terjebak untuk menciptakan kembali makna-makna yang lebih dalam dibandingkan yang disadari oleh penulis sendiri. ${ }^{29}$

Konsekuensi penafsiran yang berpusat pada pembaca membuka peluang multitafsir yang sangat subjektif dan bergantung dari emosi penafsir itu sendiri saat membangun gambaran konsep di dalam benaknya. Hal tersebut sekaligus mematahkan hegemoni penafsiran tradisional yang selama ini dipegang setia pada teks. Sebetulnya di dalam hal ini, RRC adalah alat yang dipakai oleh posttruth untuk membiarkan pembaca membentuk opininya sendiri berdasarkan sajian teks yang sejak awal disusun dalam disorientasi informasi yang terstruktur.

Dalam teorinya tentang masyarakat sebagai kenyataan subjektif, Berger dan Luckman menjelaskan bahwa fenomena ini merupakan bagian alami dari dari manusia yang mencoba mengambil alih dunia ini dan memodifikasinya secara kreatif atau malahan menciptakannya kembali dalam sebuah proses yang disebut

\footnotetext{
28 "Reader-Response Criticism," in Modern Literary Theory and Ancient Texts, 2008. (https://doi.org/10.1002/9780470692295.ch6); Michel Grimaud dan Jane P. Tompkins, "Reader-Response Criticism: From Formalism to Post-Structuralism," The Journal of Aesthetics and Art Criticism, 2006. (https://doi.org/10.2307/430832).

${ }^{29}$ Osborne, The Hermeneutical Spiral, 565-71.
} 
sebagai internalisasi. ${ }^{30} \mathrm{Hal}$ inilah yang kemudian diambil alih oleh RRC sebagai metode kritik dalam mengkritisi teks media. Maka dapat diduga, dengan pola seperti itu, akan muncul sangat banyak ide tentang makna sebagai hasil penafsiran terhadap satu teks sumber. Hal inilah yang memunculkan fenomena perang informasi di dalam dunia maya. Semakin banyak yang terlibat, akan semakin banyak proses internalisasi. Hal itu berarti, ruang bagi modifikasi dan penciptaan kembali menjadi terbuka sangat lebar.

Berdasarkan uraian di atas, dapat disimpulkan bahwa perangkat kerja hermeneutika dalam RRC tidak lagi bergantung pada teks tetapi semata-mata bergantung pada pembaca sebagai pemilik makna. Dilihat dari konsep hoax dan paradigma post-truth, RRC dapat membuka jalan bahkan hingga pada penyusunan teks demi mengarahkan khalayak untuk menarik kesimpulan yang seragam sebagai sebuah hasil penafsiran. Internalisasi semacam ini sangat kuat dan bersifat brainwash karena membangkitkan keyakinan pribadi secara internal untuk membangun kebenaran. Keyakinan tersebut semakin kuat ketika ide yang seragam ini saling bertemu di dalam kelompok dan saling melengkapi sehingga terbentuk konsensus kebenaran. Oleh sebab itu, prinsip kehati-hatian harus diterapkan. Sebab, kesalahan pemahaman yang terbentuk dari internalisasi, dapat membentuk dan melahirkan ideologi, yang amat sangat susah dibentuk ulang ketika menjadi sebuah keyakinan.

Menciptakan dan menggiring opini hanyalah hasil awal dari kritik RRC. Jika diperdalam RRC akan membentuk ideologi. Pada konteks tersebut, kata, kalimat dan pengertian yang muncul tidak lagi semata-mata dilihat dari persoalan teknis linguistik tetapi ekspresi dari ideologi. Melaluinya, pendapat umum terbentuk, diteguhkan dan mendapat legitimasi sepihak dengan pengucilan pihak lain. RRC sejak awal sudah memproduksi posisi pembacaan untuk khalayak. ${ }^{31}$

\section{Konstruksi Agama dalam Re-konstruksi Media}

Pertanyaan besar yang tersisa adalah bagaimana beragama dan mengembangkan hidup rohani yang saleh (spiritualitas) di dalam kehidupan sosial budaya dan politik dewasa ini yang sangat diwarnai

30 Peter L Berger dan Thomas Luckmann, Tafsir Sosial Atas Kenyataan (Jakarta: LP3ES, 2018), 177.

31 Badara, Analisis Wacana, 55. 
dengan hoax dan semangat post-truth di dalam cara berpikir, bertutur dan bertindak?

Hoax, paradigma post-truth dan kritik RRC di dalam konstruksi kehidupan beragama, tentu saja melahirkan persoalan yang sangat serius. Hal yang pertama-tama terjadi adalah bergesernya hegemoni terhadap tafsir kebenaran. Ketika umat dibawa melampaui teks, maka kebenaran yang muncul menjadi terpolarisasi. Tidak ada lagi kebenaran tunggal sebagai dasar keyakinan bersama yang mengikat dan mempersatukan. Hal ini dianggap sebagai konsekuensi dari sekularisasi yang selalu berusaha meminggirkan agama ke ranah privat. ${ }^{32}$ Madung mengatakan bahwa post-sekularisme muncul sebagai antitesis atas fenomena masyarakat sekular baik secara empiris maupun normatif. ${ }^{33}$ Akan tetapi, masalah menyangkut fenomena post-sekularisme ini mudah ditebak melalui gugatan terhadap kemapanan dan munculnya ancaman terhadap kemajemukan. Keragaman menjadi "barang" yang menjadi sulit dipertahankan karena setiap orang memegang kebenaran sendiri yang sudah berubah menjadi ideologi dan identitas kelompok. Hal yang diyakini benar pada satu sisi sekaligus menjadi bantahan atas kebenaran yang sederajat di sisi yang berseberangan, yang dianut oleh orang lain. Polarisasi tafsir justru menjadi ancaman bahkan pembunuh kemajemukan yang menggerus toleransi dan sikap saling menghargai keyakinan penganut agama lain.

Hal kedua yang terjadi adalah menguatnya narasi dan ekspresi kebencian di kalangan kelompok yang bersatu secara ideologi dan ironisnya justru kelompok tersebut tampil sebagai kelompok dengan identitas agama. Narasi keagamaan mengalami perubahan fungsi dari membangun iman dan kedewasaan rohani menjadi senjata mematikan untuk menyerang orang lain yang berseberangan secara keyakinan, secara politik bahkan dalam hal ide dan kebenaran. Padahal, sejatinya agama justru menjadi alat perubahan yang efektif di tengah masyarakat untuk tujuan mempersatukan dan bukan untuk memecah-belah. Lubis mengingatkan bahwa sebagai agen perubahan, agama dan ajarannya

32 Sonny Eli Zaluchu, "Mengkritisi Teologi Sekularisasi," Kurios 4, no. 1 (2018): 26. (https://doi.org/10.30995/kur.v4i1.31).

33 Otto Gusti Madung, Post-Sekularisme, Toleransi dan Demokrasi (Flores, NTT: Penerbit Ledalero, 2017), 30. 
seharusnya dibawa dan diarahkan untuk menciptakan perubahan sosial yang kondusif, sehingga kelangsungan hidup masyarakat dapat terlihara akibat semangat kooperatif anggota-anggotanya. ${ }^{34}$ Bukan justru ditunggangi sebagai alat ujaran kebencian kepada rezim pemerintah, lawan politik dan sesama anggota masyarakat bahkan pemeluk agama lain.

Fenomena ini sudah menjadi sebuah wabah yang menjadi epidemi di dalam media sosial. Terlebih yang berkaitan dengan agama dan keyakinan, ujaran kebencian yang muncul justru hadir melegalkan dirinya melalui simbol-simbol agama melalui para pelakunya. ${ }^{35}$ Maka kehidupan beragama di dalam kemajemukan menjadi sesuatu yang tidak nyaman dan menyenangkan. Hatespeech menyebabkan agama yang seharusnya ujung tombak dalam menyebarkan kasih dan membawa damai, justru bertindak menjauhi natur rahmat yang melekat kepadanya. Apakah semua ini harus dibiarkan terjadi?

Komaruddin Hidayat memberikan jawaban yang sangat meneduhkan dalam bukunya berjudul Agama untuk Peradaban. ${ }^{36} \mathrm{Di}$ dalam salah satu esainya mengenai agama, dikatakannya bahwa dalam konteks Indonesia, agama adalah sebuah rumah besar dan kukuh sejak lahir dan tumbuh sampai mati. Semua aktivitas kehidupan sosial tidak lepas dari kesadaran beragama. Oleh karena itu, ideologi sekuler sejatinya tidak memiliki ruang untuk berkembang di Indonesia secara leluasa. Ibarat rumah, agama seharusnya memberikan keamanan dan kenyamanan bagi penghuni dan tetangganya. Konsep seperti inilah yang seharusnya menjadi pola di dalam setiap usaha mengkonstruksi agama di tengah peradaban digital yang sedang melaju sangat pesat tanpa peduli terhadap kesiapan orang. Jika agama sudah tidak lagi menjadi rumah

34 Ridwan Lubis, Sosiologi Agama: Memahami Perkembangan Agama dalam Interaksi Sosial (Jakarta: Kencana Prenada Media Group, 2017), 100.

35 Sri Mawarti, "Fenomena Hate Speech Dampak Ujaran Kebencian," Toleransi 10, no. 1 (2018): 83-95. (http://ejournal.uinsuska.ac.id/index.php/toleransi/article/view/5722/3330); Budi Rizki Husin Meri Febriyani, Sunarto DM, "Analisis Faktor Penyebab Pelaku Ujaran Kebencian (Hate Speech) dalam Media Sosial," Poenale: Jurnal Bagian Hukum Pidana, Vol. 6, No. 3, (2018) 1-14.

36 Komaruddin Hidayat, Agama Untuk Peradaban: Membumikan Etos Agama dalam Kehidupan (Jakarta: Alvabet, 2019), 3-4. 
yang menjadi sumber rahmat dan kasih bagi semesta ${ }^{37}$ maka spiritualitas yang hakiki akan hilang dan digantikan oleh messy spirituality. Michael Yaconelli penulis buku Messy Spirituality menjelaskan bahwa istilah ini merujuk pada spiritualitas yang kacau akibat kerohanian yang palsu yang tidak bersandar pada kebenaran sejati. ${ }^{38}$

\section{Penutup}

Dibutuhkan usaha dan kerja keras agar pembelokan informasi karena hoax, dan reinterpretasi kebenaran karena paradigma post-truth dalam semangat kritik reader-response-criticism tidak melencengkan agama menjadi kehilangan identitas dirinya sendiri. Gagasan tentang Islam rahmatan-lil-alamin dapat menjadi model untuk mempertahankan spiritualitas sejati. Model ini oleh Yahya dikatakan, dapat memetakan hubungan antar manusia dalam konsep pluralis, humanis dalam tataran horizontal, dialogis menyangkut persoalan di dalam interaksi sosial dan toleran bagi pemeluk agama lain. ${ }^{39}$

Yang tidak kalah penting adalah pengembangan strategi literasi di semua lini. Hanya dengan cara ini masyakarat menjadi kebal terhadap usaha-usaha disinformasi dan menjadi abai terhadap disinformasi. Literasi digital adalah sebuah tahap edukasi yang membuka mata khalayak bahwa dunia berubah dan di dalam dunia yang berubah tersebut, setiap orang dituntut mengembangkan sikap yang benar, dan bertanggung jawab. Literasi mampu membentuk filter internal di dalam diri masyarakat untuk menyaring setiap informasi dan menentukan sikap terhadapnya. Jika memegang prinsip RRC dimana kendali penafsiran berada di tangan pembaca, maka pembacalah yang berhak memutuskan kebenaran setiap informasi tersebut sebelum melangkah untuk menafsirkannya.

Argumentasi Hermawan ${ }^{40}$ di dalam bukunya Literasi Media dapat dijadikan kesimpulan. Secara natural setiap manusia memiliki

\footnotetext{
37 Ibid., 4.

38 Michael Yaconelli, Messy Spirituality (Grand Rapids, Michigan: Zondervan Publishing House, 2002).

39 Ismail Yahya, "Islam Rahmatan Lil'alamin," 2018. (http://www.iainsurakarta.ac.id/?p=12750).

${ }^{40}$ Herry Hermawan, Literasi Media: Kesadaran Dan Analisis (Yogyakarta: Calpulis, 2017), 5 .
} 
pemicu di dalam dirinya menyangkut pesan-pesan media yang ada di sekitarnya. Pemicu tersebut, tanpa disadari, dapat sinkron secara otomatis ketika pesan media menjadi selaras dengan kebutuhan dan tujuan tertentu. Ketika itulah media berfungsi untuk menjadi pemegang kendali dan mengkondisikan orang ke dalam kebiasaan yang dikehendaki olehnya. Di sinilah literasi media mengambil peran. Fungsi tersebut dibalik karena kontrol bukan lagi berada di tangan media tetapi di tangan penafsir. Manusialah yang menentukan, informasi dan media mana yang layak diterima dan dipercaya dan mana yang ditolak.

\section{Daftar Pustaka}

Akbarayansyah, Andhika. "771 Hoax Berhasil Diidentifikasi Kominfo.” (detik.com, 2019).

Anisa, Renata dan Rachmaniar. "Hoax Politik Pada Media Sosial Instagram (Studi Etnografi Virtual Tentang Keberadaan Instagram dan Hoax Politik)." Prosiding Seminar Nasional Komunikasi 2016, 2016.

Badara, Aris. Analisis Wacana. Jakarta: Kencana Prenada Media Group, 2014.

Baker, Joy Don. "The Purpose, Process, and Methods of Writing a Literature Review." AORN Journal 103, no. 3 (2016). (https://doi.org/10.1016/j.aorn.2016.01.016).

Berger, Peter L. dan Luckmann, Thomas. Tafsir Sosial Atas Kenyataan. Jakarta: LP3ES, 2018.

Dossey, Larry. "Post-truth, Truthiness, and Healthcare." Explore: The Journal of Science and Healing, 2017. (https://doi.org/10.1016/j.explore.2017.03.001).

Fitri, Sulidar. "Dampak Positif dan Negatif Sosial Media." Naturalistic: Jurnal Kajian Penelitian Pendidikan Dan Pembelajaran, Vol 1, No. 2 (April, 2017). (https://doi.org/10.35568/naturalistic.v1i2.5).

Grimaud, Michel dan Tompkins, Jane P. "Reader-Response Criticism: From Formalism to Post-Structuralism." The Journal of Aesthetics and Art Criticism, 2006. (https://doi.org/10.2307/430832).

Gunawan, Budi dan Ratmono, Barito Mulyo. Kebohongan Di Dunia Maya. Jakarta: Kepustakaan Populer Gramedia, 2018. 
Hartono, Dudi. "Era Post-truth: Melawan Hoax Dengan Fact Checking." Prosiding Seminar Nasional Prodi Ilmu Pemerintahan Fisip Untirta, 2018. (http://repository.fisipuntirta.ac.id/952/).

Haryatmoko. "Era Post Truth dan Prasangka Negatif," dalam Agus Suwignyo (ed.), Post-truth Dan (Anti) Pluralisme. Jakarta: Penerbit Buku Kompas, 2018.

Hermawan, Herry. Literasi Media: Kesadaran Dan Analisis. Yogyakarta: Calpulis, 2017.

Hidayat, Komaruddin. Agama Untuk Peradaban: Membumikan Etos Agama dalam Kehidupan. Jakarta: Alvabet, 2019.

Husin, Budi Rizki, et al. "Analisis Faktor Penyebab Pelaku Ujaran Kebencian (Hate Speech) dalam Media Sosial." Poenale: Jurnal Bagian Hukum Pidana, Vol. 6, No. 3 (2018).

Ismiati, Heni , Herdiansah, Ari Ganjar dan Junaidi. "Pembelahan Ideologi, Kontestasi Pemilu, dan Persepsi Ancaman Keamanan Nasional: Spektrum Politik Indonesia Pasca 2014?” Jurnal Wacana Politik, Vol. 2, No. 1, (2017).

Juliswara, Vibriza. "Mengembangkan Model Literasi Media yang Berkebhinnekaan dalam Menganalisis Informasi Berita Palsu (Hoax) di Media Sosial." Jurnal Pemikiran Sosiologi 4, no. 2 (2017). (https://doi.org/10.22146/jps.v4i2.28586).

Kumar, Srijan, Robert West, dan Jure Leskovec. "Disinformation on the Web: Impact, Characteristics, and Detection of Wikipedia Hoaxes." The International World Wide Web Conference Com- Mittee (IW3C2), 2016. (https://doi.org/10.1145/2872427.2883085).

Llorente, Jose Antonio. "The Post-truth Era: Reality vs Perception." Uno Magazine, (March 2017). (www.U-Magazine.com).

Lubis, Ridwan. Sosiologi Agama: Memahami Perkembangan Agama dalam Interaksi Sosial. Jakarta: Kencana Prenada Media Group, 2017.

Madung, Otto Gusti. Post-Sekularisme, Toleransi dan Demokrasi. Flores, NTT: Penerbit Ledalero, 2017.

Mawarti, Sri. "Fenomena Hate Speech Dampak Ujaran Kebencian." Toleransi 10, no. 1 (2018). (http://ejournal.uinsuska.ac.id/index.php/toleransi/article/view/5722/3330).

Mastel. "Hasil Survey Wabah Hoax Nasional 2019." 2019. (https://mastel.id/hasil-survey-wabah-hoax-nasional-2019/). 
McLuhan, Mashall dan Powers, Bruce R. The Global Village: Transformation in World Life and Media. New York: Oxford University Press, 1989.

Osborne, Grant R. The Hermeneutical Spiral. Illionis: IVP Academic, 2006.

Osler, Starksey. Changing Citizenship. London: Open University Press, 2005.

Rochlin, Nick. "Fake News: Belief in Post-truth." Library Hi Tech, (2017). (https://doi.org/10.1108/LHT-03-2017-0062).

Sartana dan Nelia Afriyeni. "Perilaku Perundungan Maya (Cyberbullying) Pada Remaja Awal." Jumal Psikologi Insight (C) Psikologi Universitas Pendidikan Indonesia, Vol. 1, no. 1 (April 2017). (https://doi.org/10.5281/zenodo.576972).

Savitri, Astrid. Revolusi Industri 4.0: Mengubah Tantangan Menjadi Peluang di Era Disrupsi 4.O. Yogyakarta: Penerbit Genesis, 2019.

Sriyono. "Internet Sebagai Media Pembelajaran." Prosiding Seminar Nasional Pendidikan $\quad 2018$. (https://doi.org/10.30998/prossnp.v1i0.29).

Sumaryono, E. Hermenetik. Yogyakarta: Kanisius, 2018.

Syahputra, Iswandi. Opini Publik: Konsep, Pembentukan dan Pengukuran. Bandung: Simbiosa Rekatama Media, 2018.

Syuhada, Kharisma Dhimas. "Etika Media Di Era 'Post-truth." Jurnal Komunikasi Indonesia, 2018. (https://doi.org/10.7454/jki.v6i1.8789).

Utami, Pratiwi. "Hoax in Modern Politics." Jurnal Ilmu Sosial dan Ilmu Politik. 22, no. 2, (2019). (https://doi.org/10.22146/jsp.34614). Yaconelli, Michael. Messy Spirituality. Michigan: Zondervan Publishing House, 2002.

Yahya, Ismail. "Islam Rahmatan Lil'alamin." (http://www.iainsurakarta.ac.id/?p=12750).

Zaluchu, Sonny Eli. "Mengkritisi Teologi Sekularisasi." Kurios 4, no. 1 (2018). (https://doi.org/10.30995/kur.v4i1.31). 